\title{
PENGARUH MODEL PEMBELAJARAN READING CONCEPT MAP COOPERATIVE SCRIPT TERHADAP PEMAHAMAN KONSEP MATEMATIKA SISWA KELAS VIII
}

\author{
N. N. T. Tesashogi, N. M. S. Mertasari, I G. N. Pujawan \\ Jurusan Matematika Universitas Pendidikan Ganesha \\ Singaraja, Indonesia \\ e-mail: tesashogi@gmail.com, srimertasarinimade@yahoo.co.id, ngrpujawan@yahoo.co.id
}

\begin{abstract}
Abstrak
Penelitian ini bertujuan untuk mengetahui pengaruh model pembelajaran reading concept map cooperative script (Remap CS) terhadap pemahaman konsep matematika siswa. Jenis penelitian yang digunakan adalah eksperimen semu dengan desain penelitian posttest only control group. Populasi dalam penelitian ini adalah seluruh siswa kelas VIII SMP Negeri 4 Singaraja tahun ajaran 2018/2019. Pengambilan sampel dilakukan dengan teknik random sampling untuk memperoleh 2 kelas sebagai sampel penelitian. Data pemahaman konsep matematika siswa dikumpulkan melalui tes berbentuk uraian yang diberikan di akhir penelitian. Dari data post-test diperoleh rata-rata pemahaman konsep matematika siswa yang mengikuti pembelajaran dengan model pembelajaran Remap CS adalah 75,52 dan rata-rata pemahaman konsep matematika yang mengikuti pembelajaran konvensional adalah 65. Dari hasil analisis menggunakan uji-t satu ekor dengan taraf signifikansi $5 \%$ diperoleh nilai $t_{\text {hitung }}=3,322$ dan $t_{\text {tabel }}=1,999$, sehingga $t_{\text {hitung }}>t_{\text {tabel }}$. Dapat disimpulkan bahwa pemahaman konsep matematika siswa yang mengikuti pembelajaran dengan model pembelajaran Remap CS lebih tinggi daripada pemahaman konsep matematika siswa yang mengikuti pembelajaran konvensional. Dengan kata lain model pembelajaran Remap CS berpengaruh positif terhadap pemahaman konsep matematika siswa.
\end{abstract}

Kata kunci: model pembelajaran reading concept map cooperative script, pemahaman konsep matematika, pembelajaran konvensional

\begin{abstract}
This research was aimed to find out the effect of the reading concept map cooperative script (Remap CS) learning model toward understanding students mathematical concepts. This research is a quasi experiment using post-test only control group design. The population of this research were all VIII grade students at SMP Negeri 4 Singaraja in the academic year 2018/ 2019. Two classes were selected as sample by using random sampling technique. The data of understanding students mathematical concepts were obtained throught an essay test given at the end of the study. The post-test data showed that the average of understanding the mathematical concepts of students who studied using Remap CS learning model is 75,52 and the average of understanding the mathematical concepts of students who studied using conventional learning is 65 . The data were analyzed using one tailed t-test with a significance level of $5 \%$ shows that $t_{\text {count }}=$ $3,322>t_{\text {table }}=1,999$. This means that understanding the mathematical concepts of students who studied using Remap CS learning model is higher than understanding the mathematical concepts of students who studied using convensional learning. In other words the Remap CS learning model has a positive effect on understanding students mathematical concepts.
\end{abstract}

Keywords: reading concept map cooperative script learning model, understanding the mathematical concepts, convensional learning 


\section{PENDAHULUAN}

Matematika merupakan salah satu ilmu pengetahuan yang memiliki peranan penting karena matematika merupakan penunjang dari ilmu lainnya seperti fisika, kimia, ekonomi, dll. Matematika diberikan kepada semua siswa mulai dari jenjang sekolah dasar hingga perguruan tinggi yang bertujuan untuk membekali mereka dengan kemampuan berfikir logis, analitis, sitematis, kritis, kreatif dan kemampuan bekerjasama. Berdasarkan lampiran Permendikbud Nomor 59 Tahun 2014 menyatakan bahwa tujuan pembelajaran matematika salah satunya adalah memahami konsep matematika, merupakan kompetensi dalam menjelaskan keterkaitan antar konsep dan menggunakan konsep maupun algoritma, secara luwes, akurat, efisien, dan tepat dalam pemecahan masalah. National Council of Teacher of Mathematics (NCTM, 2000a) menyatakan bahwa pemahaman konsep merupakan komponen keahlian atau kemampuan yang penting karena konsep matematika sifatnya hierarki artinya siswa harus memahami konsep sebelumnya untuk mempermudah siswa memahami konsep selanjutnya. Ketika siswa telah memahami konsep barulah diperlukan keterampilan untuk menyelesaikan permasalahan yang kompleks menggunakan konsep tersebut. Ini berarti pemahaman konsep yang kuat dalam matematika merupakan tonggak utama dan sangat membantu siswa dalam menyelesaikan permasalahan terkait matematika.

Pada kenyataannya, salah satu masalah pokok dalam pembelajaran matematika Indonesia adalah masih rendahnya pemahaman siswa terhadap materi pelajaran matematika. Hal ini dapat dilihat dari hasil riset Trends in International

Mathematics and Science Study (TIMSS) pada tahun 2015 yang dimuat dalam harian kompas yang menyatakan bahwa Indonesia berada di peringkat ke-45 dari 50 negara yang disurvei (Prahara, 2017). Soal-soal dalam tes TIMSS menilai tiga domain kognitif salah satunya yaitu pengetahuan yang mencangkup fakta-fakta dan konsep. Dalam domain pengetahuan ini rerata persentase jawaban benar siswa Indonesia adalah 32 sementara internasional sebesar 56. Bahkan untuk soal yang sifatnya rutin siswa yang benar menjawab hanya $57 \%$ dari seluruh siswa Indonesia yang mengikuti tes (Kemendikbud, 2016).

Pembelajaran matematika yang seharusnya dijadikan salah satu pelajaran yang diminati oleh siswa di sekolah, namun pada kenyataannya siswa tidak menyukai pelajaran matematika, karena siswa merasa pelajaran tersebut sulit dan menjadi pelajaran yang membosankan. Salah satu kesulitan siswa dalam pelajaran matematika adalah karakteristik matematika yang bersifat abstrak. Kesulitan siswa tersebut muncul karena pembelajaran yang dilakukan di kelas biasanya guru kurang menanamkan diskusi dua arah dalam pembelajaran, siswa kurang dilatih untuk menyampaikan pemahaman yang mereka dapat, dan siswa jarang membuat rangkuman materi. Pemahaman yang siswa dapat baik dari guru atau membaca biasanya berbeda, hal ini bisa disebabkan karena kemampuan mereka juga berbeda dalam menerima materi pembelajaran dan berbeda dalam daya ingat (Loviana, 2013). Sedangkan pemahaman konsep yang matang dalam pembelajaran matematika sangat penting untuk memecahkan masalah pada matematika dengan baik. Dalam pembelajaran matematika, pemahaman konsep merupakan salah satu aspek penting yang harus dikuasai siswa. Tanpa adanya pemahaman terhadap konsep/ materi maka siswa akan sulit bahkan tidak bisa mengaplikasikan materi yang diperoleh untuk menyelesaikan permasalahan yang mungkin ada dalam kehidupan sehari harinya.

$\begin{array}{lcr}\text { Untuk } & \text { mengatasi } & \begin{array}{r}\text { berbagai } \\ \text { problematika }\end{array} \\ \text { dalam } & \text { pelaksanaan } \\ \text { pembelajaran, } & \text { diperlukan model-model } \\ \text { pembelajaran yang dipandang mampu }\end{array}$


mengatasi kesulitan guru dalam melaksanakan tugas mengajar dan juga kesulitan belajar siswa. Joyce \& Weil (dalam Sumantri, 2015) mendefinisikan model pembelajaran sebagai kerangka konseptual yang digunakan sebagai pedoman dalam melakukan kegiatan pembelajaran. Dengan demikian, model pembelajaran merupakan kerangka konseptual yang melukiskan prosedur yang sistematis dalam mengorganisasikan pengalaman belajar untuk mencapai tujuan belajar. Model pembelajaran yang mampu menciptakan keaktifan siswa di kelas dan memiliki tahapan merangkum materi berupa peta konsep dalam pembelajarannya yang secara tidak langsung menyebabkan siswa haruslah membaca setiap materi pelajaran yang akan diberikan adalah model pembelajaran Reading Concept Map Cooperative Script (Remap CS).

Model pembelajaran Remap CS adalah integrasi antara model pembelajaran Reading Concept Map Cooperative learning (Remap Coople) dan pembelajaran Cooperative Script (CS). Remap Coople merupakan model pembelajaran yang mengharuskan siswa membaca (proses reading), kemudian siswa diminta membuat peta konsep (concept mapping) dan pembelajarannya menggunakan modelmodel cooperative learning (Zubaidah, 2014). Sedangkan model pembelajaran Cooperative Script merupakan model pembelajaran yang dapat meningkatkan daya ingat siswa (dalam Shoimin, 2014).

Model pembelajaran Remap CS terdiri dari 6 tahapan, sebagai berikut: 1) Tahap pertama, membentuk kelompok kecil dan menyampaikan topik bacaan yang akan dibaca siswa; 2) Tahap kedua, siswa membaca bacaan dan memahami isi dari bacaan. Setelah siswa membaca, dalam pikirannya akan tersusun kata-kata sendiri untuk memaknai konsep tersebut sehingga siswa akan mampu menyatakan ulang konsep yang telah dipelajari dengan katakata sendiri dan siswa akan mengidentifikasi yang termasuk contoh dan bukan contoh dari materi tersebut; 3) Tahap ketiga, siswa meringkas bacaan dengan menuliskan ideide pokok dan menyusun dalam bentuk peta konsep. Pada saat meringkas bacaan melalui peta konsep yang dibuat sendiri, siswa akan dapat menuliskan konsep dengan kata-katanya sendiri dan mengidentifikasikan mana yang termasuk contoh dan bukan contoh dalam suatu materi; 4) Tahap keempat, siswa saling membacakan atau memperlihatkan hasil ringkasan dalam kelompok kecil dan saling mengoreksi peta konsep. Pada tahap ini siswa dapat mengungkapkan kembali pemahaman yang mereka peroleh dari membaca dan meringkas dalam bentuk peta konsep dengan menyatakan ulang konsep yang telah dipelajari dengan kata-kata sendiri dan siswa akan mengidentifikasi yang termasuk contoh dan bukan contoh dari materi tersebut; 5) Tahap kelima adalah mengelaborasi pengetahuan yang telah didapat untuk menyelesaikan soal yang terdapat dalam LKS dan diskusi. Pada tahap ini siswa diberi kesempatan untuk menerapkan konsep yang baru diperoleh ke dalam latihan soal. Dengan kata lain, siswa dapat mengaplikasikan/ menggunakan konsep dengan benar ke dalam berbagai situasi; 6) Tahap terakhir yaitu menyusun kesimpulan materi pembelajaran yang telah dipelajari. Pada tahap ini siswa menyusun kesimpulan dari pembelajaran bersama dengan guru dan sampai dengan tahap terakhir ini, siswa telah mengalami ketiga proses dari indikator pemahaman konsep tersebut, yaitu menyatakan ulang konsep yang telah dipelajari dengan kata-kata sendiri dan siswa akan mengidentifikasi yang termasuk contoh dan bukan, mengaplikasikan/ menggunakan konsep dengan benar ke dalam berbagai situasi.

Pemilihan CS sebagai pembelajaran kooperatif yang dipadukan dengan RemapCoople adalah karena: 1) merupakan pembelajaran kooperatif yang dapat memfasilitasi siswa untuk bekerjasama dan bertanggung jawab terhadap teman satu kelompoknya, sehingga membuat setiap siswa belajar sama baiknya untuk mencapai tujuan pembelajaran; 2) pembelajaran CS 
menuntut setiap siswa untuk berperan aktif dalam proses saling mengoreksi dan memperbaiki hasil ringkasan yang dapat memunculkan sifat ulet, meningkatkan kerja mandiri, demokratis, ketelitian, belajar menerima pendapat orang lain, sikap kritis, saling bekerjasama (melengkapi) antar siswa (Kurniawati, 2016b).

Beberapa hasil penelitian yang dilakukan oleh peneliti, seperti penelitian yang dilakukan oleh Zenia Lutfi Kurniawati, dkk (2016a) menyatakan bahwa pembelajaran dengan model Remap CS berpengaruh positif untuk memberdayakan keterampilan berpikir kritis siswa. Dengan meningkatnya kemampuan berpikir kritis, maka dipastikan pemahaman konsep juga telah meningkat, sehingga dapat dilihat keterkaitan antara kemampuan berpikir kritis dengan pemahaman konsep. Penelitian yang dilakukan oleh Shalihati (2016) menunjukan bahwa dengan model pembelajaran Cooperative Script rata-rata hasil belajar siswa dalam pelajaran matematika mengalami peningkatan. Untuk mencapai hasil belajar yang maksimal, salah satu komponen yang harus dimaksimalkan adalah pemahaman konsep. Sehingga terdapat keterkaitan yang sangat erat antara pemahaman konsep dengan hasil belajar siswa. Jika hasil belajar meningkat maka secara tidak langsung dapat diartikan pemahaman konsep siswa telah mengalami peningkatan sebelumnya. Dari hasil penelitian yang telah dipaparkan, model pembelajaran Remap CS berpengaruh positif terhadap pemahaman konsep matematika siswa. Sintaks dalam model Remap CS memberikan kesempatan kepada siswa untuk menggali pengetahuan dan mengharuskan siswa untuk berperan aktif dalam proses pembelajaran.

Berdasarkan uraian diatas, peneliti tertarik untuk melakukan penelitian mengenai pengaruh model pembelajaran Reading Concept Map Cooperative Script (Remap CS) terhadap pemahaman konsep matematika siswa. Penelitian ini berjudul "Pengaruh Model Pembelajaran Reading Concept Map Cooperative Script (Remap
CS) terhadap Pemahaman Konsep Matematika pada Siswa Kelas VIII SMP Negeri 4 Singaraja".

\section{METODE}

Jenis penelitian ini adalah penelitian eksperimen, dalam kategori penelitian eksperimen semu (quasi eksperiment). Penelitian semu dapat digunakan untuk melihat pengaruh yang ditimbulkan dari perlakuan berbeda yang diberikan pada masing-masing kelompok, dimana peneliti tidak dapat mengontrol semua variabel dan kondisi eksperimen secara ketat. Penelitian ini bertujuan untuk mengetahui pengaruh penerapan model pembelajaran Remap CS terhadap pemahaman konsep matematika siswa kelas VIII SMP Negeri 4 Singaraja. Jumlah siswa kelas VIII non unggulan di SMP Negeri 4 Singaraja adalah 284 orang siswa. Teknik pengambilan sampel dilakukan dengan teknik random sampling. Dalam pengambilan sampel tersebut akan dipilih dua kelas, satu kelas sebagai kelas eksperimen dan satu kelas lagi sebagai kelas kontrol. Pada kelas kontrol akan digunakan pembelajaran konvensional, sedangkan pada kelas eksperimen akan digunakan model pembelajaran Remap CS.

Sebelum dilakukan pengambilan sampel secara acak, dilakukan uji kesetaraan sampel dengan menguji nilai ulangan akhir semester pada mata pelajaran matematika siswa kelas VIII semester ganjil tahun ajaran 2018/2019. Uji yang digunakan adalah uji ANAVA satu jalur yang sering disebut dengan uji $F$. berdasarkan penyetaraan yang dilakukan, diperoleh nilai $F_{\text {hitung }}=1,605$ dan $F_{0,05(8,275)}=1,972$, sehingga $F_{\text {hitung }} \leq F_{\text {tabel }}$, oleh karena itu dapat dikatakan bahwa kesembilan kelas penelitian tersebut setara.

Penentuan kelas yang menjadi kelas kontrol, dan kelas eksperimen dilakukan secara random dengan sistem pengundian. Hasilnya adalah terpilihnya kelas VIII B5 sebagai kelas kontrol, dan VIII B6 sebagai kelas eksperimen. Pada kelompok eksperimen diterapkan model pembelajaran 
Remap CS, dan pada kelompok kontrol diterapkan pembelajaran konvensional.

Variabel penelitian adalah "segala sesuatu yang berbentuk apa saja yang ditetapkan oleh peneliti untuk dipelajari sehingga diperoleh informasi kemudian ditarik kesimpulannya" (Sugiyono, 2017:60). Ada dua jenis variabel yang terlibat dalam penelitian ini, yaitu variabel bebas (independent variable) dan variabel terikat (dependent variable). Penelitian ini menyelidiki pengaruh dua variabel bebas terhadap variabel terikat.

Variabel bebas adalah variabel bebas dalam penelitian ini adalah model pembelajaran Reading Concept Map Cooperative Script (Remap CS) yang diterapkan pada kelompok eksperimen dan pembelajaran konvensional yang diterapkan pada kelas kontrol. Variabel terikat yang diteliti dalam penelitian ini adalah pemahaman konsep matematika siswa.

Rancangan (desain) penelitian yang digunakan adalah post test only control group design. Terdapat dua kelompok yang menjadi sampel penelitian ini yaitu kelompok eksperimen, dan kelompok kontrol. Kelompok eksperimen diberi perlakuan berupa penerapan model pembelajaran Remap CS. Kelompok kontrol diberi perlakuan berupa penerapan pembelajaran konvensional. Setelah itu kedua kelompok diberi post-test.

Jenis instrumen yang digunakan dalam penelitian ini ialah berupa tes. Data yang akan dikumpulkan pada penelitian ini adalah pemahaman konsep matematika siswa yang diperoleh melalui tes pemahaman konsep matematika. Tes ini akan diberikan pada akhir pertemuan pada kedua kelas sampel. Tes pemahaman konsep matematika akan yang akan digunakan pada penelitian ini berupa tes uraian/ essay. Indikator pemahaman konsep matematika yang digunakan dalam penelitian ini adalah indikator yang diuraikan dalam NCTM (2000b) yaitu (1) Menyatakan ulang konsep yang telah dipelajari dengan kata-kata sendiri, (2) Mengidentifikasikan yang termasuk contoh atau bukan contoh dari konsep, (3) Mengaplikasikan/ menggunakan konsep dengan benar dalam berbagai situasi. Indikator ini yang dijadikan pedoman dalam penyusunan rubrik penskoran tes pemahaman konsep matematika siswa.

Instrumen penelitian sebelum diberikan kepada siswa yang menjadi sampel penelitian, akan dilakukan uji coba terlebih dahulu. Uji coba bertujuan untuk mendapatkan gambaran secara empirik apakah instrumen penelitian berupa tes pemahaman konsep matematika siswa layak digunakan sebagai instrumen. "Suatu tes yang dapat dikatakan baik sebagai alat pengukur harus memenuhi persyaratan tes yaitu valid dan reliable" (Arikunto, 2007:57).

Instrumen penelitian sebelum diberikan kepada siswa yang menjadi sampel penelitian, dilakukan beberapa uji untuk mendapatkan hasil yang baik. Uji coba instrumen diawali dengan penilaian oleh ahli (expert judgement) terhadap instrumen yang telah dirancang sebelumnya. Menurut Candiasa (2010), uji validitas isi digunakan untuk mengetahui validitas isi instrumen yang menyangkut tentang materi atau isi pelajaran yang diajarkan dan format penulisan. Perhitungan validitas isi dilakukan dengan formula Gregory, dari hasil perhitungan diperoleh koefisien validitas isi tes yang akan diujicobakan adalah 1,00 yang berarti tes yang akan diujicobakan sangat relevan. Setelah uji ahli/ pakar barulah dilakukan uji coba tes, yang pada penelitian ini dilakukan pada kelas yang sudah diajarkan materi lingkaran yaitu, kelas VIII.7 SMP Negeri 2 Singaraja, dimana banyak soal yang diujicobakan ada 9 butir soal.

Untuk menghitung validitas butir tes digunakan rumus korelasi Product Moment dan untuk menentukan reliabilitas tes digunakan formula Alpha Cronbach. Dari hasil analisis validitas tes diperoleh bahwa dari 9 soal yang diujicobakan ternyata terdapat 6 butir soal valid yang selanjutnya soal valid ini diuji reliabilitasnya, yaitu 0,624. Hasil tersebut menunjukkan bahwa tes yang bertujuan untuk mengukur pemahaman 
konsep matematika siswa tersebut reliabel dengan tingkat reliabilitas tinggi, sehingga soal-soal tersebut layak untuk digunakan. Semua soal valid dan reliabel kemudian digunakan sebagai post test, karena keenam soal tersebut sudah mencakup keseluruhan materi yang diajarkan. Total skor maksimal dari soal post-test tersebut adalah 30 .

Selanjutnya sampel akan diberikan uji post-test untuk mencari skor dari tes pemahaman konsep matematika siswa. Data hasil penelitian dianalisis secara bertahap, Tahapan-tahapan tersebut adalah analisis data, uji prasyarat dan uji hipotesis. Uji prasyarat yang dilakukan adalah uji normalitas sebaran data dan uji homogenitas varians.

Uji normalitas sebaran data pemahaman konsep matematika siswa pada penelitian ini dianalisis dengan menggunakan uji Liliefors, data dikatakan berdistribusi normal apabila nilai $L_{\text {hitung }}<$ $L_{\text {tabel }}$ dengan taraf signifikansi $5 \%$. Homogenitas varians dari data pemahaman konsep matematika siswa pada penelitian ini dianalisis dengan uji Levene. Data dikatakan homogen jika $W<F_{\text {tabel }}$ dengan taraf signifikansi $5 \%$.

\section{HASIL DAN PEMBAHASAN}

Penelitian yang telah dilakukan di SMP Negeri 4 Singaraja menghasilkan data mengenai pemahaman konsep matematika siswa yang mengikuti pembelajaran dengan model pembelajaran Remap CS dan pemahaman konsep matematika siswa yang mengikuti pembelajaran konvensional. Data mengenai pemahaman konsep matematika siswa diperoleh melalui post-test dengan tes yang sama untuk kelompok eksperimen dan kelompok kontrol. Dari data post-test diperoleh rata-rata pemahaman konsep matematika siswa yang mengikuti pembelajaran dengan model pembelajaran Remap CS adalah 75,52 dan rata-rata pemahaman konsep matematika yang mengikuti pembelajaran konvensional adalah 65. Dapat dilihat bahwa rata-rata skor pemahaman konsep matematika siswa kelompok eksperimen yang dibelajarkan dengan model pembelajaran Remap CS lebih tinggi dari rata-rata skor pemahaman konsep matematika siswa kelompok kontrol yang mengikuti pembelajaran konvensional.

Untuk mengetahui apakah pemahaman konsep matematika siswa yang dibelajarkan dengan model pembelajaran Remap CS lebih baik daripada pemahaman konsep matematika siswa yang mengikuti pembelajaran konvensional, maka perlu dilakukan pengujian terhadap $\mathrm{H}_{0}$. Sebelum uji hipotesis dilakukan, terlebih dahulu dilakukan uji prasyarat yaitu pengujian terhadap normalitas dan homogenitas varians terhadap data pemahaman konsep matematika siswa. Hasil uji normalitas data pemahaman konsep matematika siswa pada kelompok kontrol diperoleh $L_{\text {hitung }}=$ 0,102 sedangkan pada kelompok eksperimen diperoleh $L_{\text {hitung }}=0,128$. Dengan $n=32$ pada taraf signifikansi $5 \%$ diperoleh $L_{\text {tabel }}=0,153$, karena $L_{\text {hitung }}$ pada kedua kelompok sampel baik eksperimen maupun kontrol lebih kecil dari $L_{\text {tabel }}$ pada kelompok yang bersangkutan, maka $\mathrm{H}_{0}$. Ini berarti data pemahaman konsep matematika siswa berasal dari populasi yang berdistribusi normal.

Homogenitas varians dari data pemahaman konsep matematika siswa pada penelitian ini dianalisis dengan uji Levene. Hasil uji homogenitas varians data pemahaman konsep matematika untuk kedua kelompok diperoleh nilai $\mathrm{W}=0,182$ dan $F_{\text {tabel }}=3,996$ untuk taraf signifikansi sebesar $5 \%$. Karena nilai $W<F_{\text {tabel }}$ dengan taraf signifikan $5 \%$ sehingga $\mathrm{H}_{0}$ diterima. Ini berarti data pemahaman konsep matematika siswa memiliki varians yang homogen.

Hasil uji normalitas dan homogenitas yang telah dilakukan memperlihatkan bahwa data dari kelompok eksperimen dan kelompok kontrol berasal dari populasi yang berdistribusi normal dan variansnya homogen yang artinya uji prasyarat sudah terpenuhi sehingga pengujian hipotesis dapat dilakukan dengan menggunakan uji-t satu ekor kanan untuk melihat apakah 
pemahaman konsep matematika siswa yang dibelajarkan dengan model pembelajaran Remap CS lebih baik daripada pemahaman konsep matematika siswa yang dibelajarkan dengan pembelajaran konvensional.

Rangkuman hasil pengujian data pemahaman konsep matematika siswa dengan menggunakan Uji-t disajikan pada Tabel 1 berikut.

Tabel 1. Rangkuman Hasil Uji-t Data Pemahaman Konsep Matematika

\begin{tabular}{ccc}
\hline & \multicolumn{2}{c}{ Kelompok } \\
\cline { 2 - 3 } & Eksperimen & Kontrol \\
\hline $\boldsymbol{N}$ & 32 & 32 \\
\hline$\overline{\boldsymbol{Y}}$ & 75,52 & 65 \\
\hline $\boldsymbol{s}_{\text {gab }}^{2}$ & \multicolumn{2}{c}{160,43} \\
\hline $\boldsymbol{t}_{\text {hitung }}$ & \multicolumn{2}{c}{3,322} \\
\hline $\boldsymbol{t}_{\text {tabel }}$ & \multicolumn{2}{c}{1,999} \\
\hline
\end{tabular}

Berdasarkan hasil perhitungan pada tabel 1 diatas, dari hasil uji hipotesis menggunakan uji-t satu ekor kanan diperoleh bahwa $t_{\text {hitung }}=3,322$ dan $t_{\text {tabel }}=$ 1,999 yang berarti bahwa $t_{\text {hitung }}>t_{\text {tabel }}$ untuk $\alpha=5 \%$ sehingga $\mathrm{H}_{0}$ ditolak dan $\mathrm{H}_{1}$ diterima. Artinya pemahaman konsep matematika siswa siswa yang mengikuti pembelajaran dengan model pembelajaran Remap CS lebih baik daripada pemahaman konsep matematika siswa yang mengikuti pembelajaran konvensional.

Pemahaman konsep matematika siswa pada kelompok eksperimen lebih baik daripada kelompok kontrol dikarenakan dalam pelaksanaan proses pembelajaran siswa lebih banyak memiliki kesempatan untuk mengungkapkan kembali konsep yang telah dipelajari dengan kata-kata sendiri, mengidentifikasi yang termasuk contoh dari konsep dan menerapkannya untuk menyelesaikan suatu permasalahan melalui langkah pembelajaran dengan model pembelajaran Remap CS. Dalam pembelajaran menggunakan model pembelajaran Remap CS memberi kesempatan kepada siswa untuk belajar secara mandiri, kreatif, dan lebih aktif terhadap materi yang dipelajari dan berdampak pada meningkatnya pemahaman konsep matematika siswa.

Remap CS terdiri dari 6 tahapan dan masing-masing tahapan tersebut akan dapat membantu siswa untuk membangun sendiri pemahamannya terhadap apa yang sedang mereka pelajari. Pelajaran diawali dengan membentuk siswa kedalam kelompok yang heterogen. Tahap kedua adalah siswa membaca bacaan dan memahami isi dari bacaan. Pada tahap ini guru meminta siswa untuk membaca (reading) bacaan dan memahaminya. Ketika siswa sudah memahami suatu konsep, siswa akan mudah menentukan contoh dan bukan contoh dari konsep tersebut. Dengan membaca siswa akan memperoleh perincian-perincian atau fakta-fakta (reading for details or facts)suatu konsep. Setelah siswa memperoleh informasi-informasi mengenai konsep tertentu, dalam pikirannya akan tersusun kata-kata sendiri untuk memaknai konsep tersebut.

Tahap ketiga adalah siswa meringkas bacaan dengan menuliskan ide-ide pokok dan menyusun dalam bentuk peta konsep. Dengan adanya proses meringkas ini secara langsung siswa terlebih dahulu harus membaca materi pelajaran agar dapat memahami materi yang dipelajari serta mampu untukdapat menyelesaikan permasalahan-permasalahan dengan berbagai penyelesaian alternatif. Melalui peta konsep siswa menjadi lebih mudah dalam penguasaan materi, keterkaitan antar konsep, dan mendorong siswa mencari kaitan diantara informasi karena siswa sendiri yang menyusunnya sehingga akan lebih mudah diingat.

Tahap keempat adalah siswa saling membacakan atau memperlihatkan hasil ringkasan dalam kelompok kecil dan saling mengoreksi peta konsep. Pada tahap ini siswa dapat mengungkapkan kembali pemahaman yang mereka peroleh dari membaca dan meringkas dalam bentuk peta konsep. Pada saat siswa mengoreksi peta konsep dan saling mengungkapkan kembali pendapatnya, siswa dapat menguji ide-ide mereka miliki dengan ide-ide siswa lainnya 
sehingga membantu pemahaman konsep siswa yang sudah dipelajari secara mandiri.

Tahap kelima adalah mengelaborasi pengetahuan yang telah di dapat untuk menyelesaikan soal yang terdapat dalam LKS dan diskusi. Pada tahap ini siswa diberi kesempatan untuk menerapkan konsep yang baru diperoleh ke dalam latihan soal. Hal ini bertujuan untuk lebih memperdalam pemahaman siswa dengan mengaplikasikan/ menggunakan konsep atau materi yang telah dipelajari untuk memecahkan suatu permasalahan. Pada tahap ini siswa juga membutuhkan kemampuannya untuk mengungkapkan konsep dan mengidentifikasi contoh dan bukan contoh dari konsep untuk dapat mengaplikasikan konsep ke dalam pemecahan masalah. Latihan soal siswa juga dibahas untuk mengetahui cara siswa menggaplikasikan pemahaman mereka. Tahap terakhir yaitu menyusun kesimpulan materi pembelajaran yang telah dipelajari. Pada tahap ini siswa menyusun kesimpulan dari pembelajaran bersama dengan guru dan pada tahap terakhir ini, siswa telah mengalami ketiga proses dari indikator pemahaman konsep tersebut.

Berdasarkan hasil pengujian hipotesis dan gambaran deskrif di atas, dapat dilihat bahwa pembelajaran dengan model pembelajaran Remap CS berpengaruh positif terhadap pemahaman konsep matematika siswa. Hal ini dibuktikan dengan hasil post test yang menunjukkan bahwa kemampuan pemahaman konsep matematika siswa yang mengikuti pembelajaran dengan model pembelajaran Remap CS lebih baik daripada pemahaman konsep matematika siswa yang mengikuti pembelajaran konvensional.

\section{SIMPULAN DAN SARAN}

Berdasarkan hasil penelitian dan pembahasan yang telah dipaparkan sebelumnya, dapat disimpulkan bahwa pemahaman konsep matematika siswa yang mengikuti pembelajaran dengan model pembelajaran Remap CS lebih baik daripada pemahaman konsep matematika siswa yang mengikuti pembelajaran konvensional. Dengan kata lain model pembelajaran Remap CS berpengaruh positif terhadap pemahaman konsep matematika siswa.

Adapun saran yang dapat disampaikan berdasarkan penelitian yang telah dilakukan, yaitu kepada praktisi pendidikan matematika, khususnya guru mata pelajaran matematika diharapkan dalam pembelajaran di kelas dapat menerapkan model pembelajaran Remap CS sebagai salah satu alternatif pembelajaran, mengingat model pembelajaran Remap CS memiliki pengaruh positif dalam pembelajaran terutama dalam meningkatkan pemahaman siswa terhadap konsep yang diajarkan.

Penelitian ini dilakukan hanya sebatas untuk mengetahui pengaruh model pembelajaran Remap CS terhadap pemahaman konsep matematika siswa. Bagi peneliti lain yang tertarik disarankan melakukan penelitian terkait pengaruh model pembelajaran Remap CS pada aspek pembelajaran matematika lainnya untuk mengetahui pengaruh model pembelajaran Remap CS dalam pembelajaran matematika secara lebih mendalam.

\section{DAFTAR PUSTAKA}

Arikunto, S. 2007. Dasar-Dasar Evaluasi Pendidikan (Edisi Revisi Cetakan Ketujuh). Jakarta: Bumi Aksara

Candiasa, I M. 2010. Pengujian Instrumen Penelitian Disertai Aplikasi ITEMAN dan BIGSTEPS. Singaraja: Undiksha Press

Kemendikbud. 2016. "TIMSS Infographic". Tersedia pada http://puspendik.kemdi kbud.go.id/seminar/upload/Hasil\%20S eminar\%20Puspendik\%202016/TIMS S\%20infographic.pdf (diakses 1 Juni 2018)

Kristina. 2018. "Peningkatan Pemahaman Konsep Siswa Kelas X Pada Mata 
Jurnal Pendidikan Matematika Undiksha, Volume X No 2, Agustus 2019 e-ISNN:2599-2600; p-ISNN: 2613-9677

Pelajaran Matematika Dengan Pendekatan Creative Problem Solving". Tersedia pada http://jurnal. ustjogja.ac.id/index.php/etnomatnesia I article/download/2368/1329 (diakses 15 Juni 2018)

Kurniawati, Lutfi Z. dkk. 2016. "Pemberdayaan Keterampilan Metakognitif dan Hasil Belajar Kognitif Melalui Pembelajaran Biologi Berbasis Reading Concept Map Cooperative Script (Remap CS)". Tersedia pada http://journal.um.ac.id lindex.php/iptpp/article/view/6206 (diakses 23 April 2018)

Loviana, Selvi, dkk. 2013. "Pengaruh Penerapan Metode Cooperative Script Terhadap Pemahaman Konsep Matematis Siswa". Tersedia pada http://jurnal.fkip.unila.ac.id/index.php/ MTK/article/view/378 (diakses 8 April 2018)

NCTM. 2000a. Principles and Standards for School Mathematics. USA : LCC

NCTM. 2000b. Mathematics Assessment : A Practical Handbook for Grade 6 - 8. USA : LCC

Peraturan Menteri Pendidikan dan Kebudayaan No. 59 Tahun 2014 Tentang Kurikulum 2013 Sekolah Menengah Pertama/ Madrasah Tsanawiyah

Prahara, Haris. 2017. "Pada 2020, Tak Ada Lagi Pelajaran Matematika di Negara Ini". Tersedia pada http://edukasi. kompas.com/read/2017/09/19/134456 11/ pada-2020-tak-ada-lagi-pelajaranmatematika-di-negara-ini (diakses tanggal 1 Agustus 2018)

Shoimin, Aris. 2014. 68 Model Pembelajaran Inovatif dalam Kurikulum 2013. Jakarta: Ar-Ruzz Media
Sugiyono. 2017. Metode Penelitian Pendidikan (Pendekatan Kuantitatif, Kualitatif dan R\&D). Bandung: Alfabeta

Suherman, Erman. 2003. "Strategi Pembelajaran Matematika Kontemporer. Bandung: Universitas Pendidikan Indonesia

Sumantri, Mohamad Syarif. 2015. Strategi Pembelajaran: Teori dan Praktik di Tingkat Pendidikan Dasar. Jakarta: Rajagrafindo Persada

Zubaidah, Siti. 2014. "Pemberdayaan Keterampilan Penemuan dalam Sicientific Approach melalui Pembwlajaran Berbasis Remap Coople". Tersedia pada: https://media. neliti.com/media/publications/176278ID-model-pembelajaran-remap-csreading-conc.pdf (diakses tanggal 20 Maret 2018) 